\title{
PERANCANGAN APLIKASI UNTUK PENCATATAN DAN PELAPORAN DATA SERVIS DEALER MOTOR
}

\author{
Oleh: \\ WALHIDAYAT \\ email: walhidayat82@gmail.com \\ Program Studi Manajemen Informatika \\ Fakultas Teknik \\ Universitas Islam Kuantan Singingi
}

\begin{abstract}
Abstrak
Sistem Informasi penjualan dan pelayanan service ini dapat menjadi salah satu solusi yang dapat digunakan untuk mempermudah pemilik bengkel dalam mengolah data penjualan spare part, data pelayanan service, laporan data spare part serta pembuatan nota transaksi penjualan dan pelayanan service menjadi lebih mudah cepat dan efisien sehingga dapat membantu meningkatkan pelayanan bengkel dalam menjalankan usahanya. Serta akan membantu dalam membuat keputusan yang akan membangun sistem informasi sehingga akan membantu membuat keputusan untuk meningkatkan pelayanan di bengkel.
\end{abstract}

Kata kunci: Aplikasi bengkel, pemograman visual, pendataan dan pelaporan

\section{PENDAHULUAN}

Penggunaan perangkat komputer sebagai perangkat pendukung manajemen dan pengolahan data adalah sangat tepat dengan mempertimbangkan kuantitas dan kualitas data. Dengan demikian penggunaan perangkat komputer dalam setiap informasi sangat mendukung sistem pengambilan keputusan.

Dengan sistem pendaftaran yang terkomputerisasi diharapkan akan memudahkan kasir (servis counter) dan mengurangi waktu pencarian data serta penyusunan laporan-laporan mengenai kegiatan penerimaan servis 
sepeda motor customer atau pelanggan informasi tersebut harus dapat diandalkan untuk mengolah data menjadi informasi yang bermanfaat dalam mengambil sebuah keputusan.

\section{KAJIAN TEORITIS}

\section{Konsep Manajemen Sistem dan Informasi}

Dalam kehidupan kita sehari-hari sering dijumpai berbagai masalah dari yang rumit sampai kepada masalah yang sederhana. Karena dua hal tersebut banyak manusia berusaha untuk mencari solusi terbaik bagi masalah yang dihadapi. Solusi yang digunakan itulah yang sering disebut sebagai sebuah sistem dimana nantinya bermanfaat untuk mengetahui suatu permasalahan yang luas. Untuk mendukung terciptanya sistem tersebut perlu adanya suatu informasi yang tepat dan akurat.

\section{Model Perancangan sistem}

Perancangan adalah kegiatan membuat desain teknis berdasarkan evaluasi yang telah dilakukan pada kegiatan analis.

Model perancangan sistem adalah sebagai berikut :

1. Merupakan tahapan lanjutan setelah tahap analisis sistem dalam hidup perkembangan sistem.

2. Mendefinisikan setiap kebutuhan-kebutuhan fungsional

3. Menyiapkan rancangan implementasi sistem yang baru

4. Menggambarkan sistem baru atau usulan yang akan dikembangkan.

Mengatur dan merencanakan elemen-elemen yang terpisah serta mengkonfigurasikan perangkat lunak dan keras.

\section{Konsep Pengolahan Data}

Pengolahan data dengan menggunakan komputer pada suatu sistem biasanya dilakukan oleh bagian Pengolahan Data Elektronik (PDE). Data adalah kumpulan kejadian yang diangkat dari suatu kenyataan. Data dapat berupa angka-angka, huruf-huruf, simbol-simbol khusus atau gabungan 
darinya (Pengenalan Komputer", Jogiyanto H. MBA, P. Hd, Andi Yogyakarta).

\section{Model Data}

Ada beberapa model data di dalam suatu sistem basis data. Model data adalah pemetaan yang menunjukan hubungan logika antara elemen data atau suatu cara untuk menjelaskan bagaimana pemakai dapat melihat data secara logic.. Disisi lain, sebuah model dinyatakan dalam bentuk diagram awal (preliminary design) akan lebih mudah untuk dievakuasi atau dianalisis atau kemudian dilakukan perbaikan-perbaikan untuk mendapatkan sebuah model data yang lebih permanen dan lebih mendekati kenyataan yang sesungguhnya.

Ada 2 Model yaitu :

\section{Object-Based Data Model}

Object-Based data menggunakan konsep seperti entity, attribute dan relationsip (hubungan)

a. Entity adalah suatu object yang berbeda (orang,tempat, suatu konsep atau kejadian) dalam suatu organisasi yang merupakan untuk dipresentasikan dalam suatu Data Base / Basis Data.

b. Attribute merupakan suatu sipat yang menggambarkan beberapa aspek terhadap object yang akan direkam.

c. Relationship suatu hubungan antara entity.

2. Record-Based data Model Yaitu :

a. Didalam suatu record-based model, data base / basis data terdiri dari sejumlah record dengan format yang tetap dengan kemungkinan tipe yang berbeda.

b. Setiap tipe record mendefinisikan sejumlah field yang tatap yang masing-masing panjang yang tetap.

1. Relation data model

2. Hierachical data model 


\section{Network data model}

Dalam sebuah relasi data base/basis data, tabel yang memuat kunci utama yang digunakan sebagai referensi kunci utama tabel lainnya disebut tabel induk (parent) sedangkan tabel yang memuat kunci tamu disebut tabel anak (child).

Ada 3 bentuk relasi yang lazim digunakan, antara lain :

1. Relasi one to one. Relasi ini menyatakan hanya satu record pada tabel anak yang dapat direlasikan dengan satu record pada tabel induk.

Field kunci utama yang digunakan sebagai kunci utama pada tabel lainnya disebut field relasi.

2. Relasi one to many. Relasi ini menyatakan bahwa beberapa record pada tabel anak dapat direlasikan dengan satu record pada tabel induk.

Relasi many to many. Relasi ini menyatakan bahwa beberapa record pada tabel anak dapat direlasikan dengan satu record pada tabel induk, dan sebaliknya beberapa record pada tabel induk dapat direlasikan pada satu record pada tabel anak. Namun dalam perancangan tabel Relasi many to many dari 2 tabel tidak lazim atau tidak boleh di lakukan, karna hal itu menjadikan field kunci tidak lagi bersifat unik.

\section{ANALISA RANCANGAN APLIKASI}

\section{Analisa Sistem}

Suatu sistem pada dasarnya adalah suatu susunan yang teratur dari kegiatan-kegiatan yang saling berintegrasi satu sama lainnya, dan prosedurprosedur yang dilaksanakan saling berkaitan sehingga memudahkan pelaksanaan kegiatan utama dari suatu organisasi.

Tahap analisa sistem perlu dilakukan dahulu sebelum tahap perancangan sistem dan tahap yang penting dalam merancang suatu sistem. Analisa sistem dilakukan untuk mengetahui masalah apa yang sebenarnya dihadapi oleh Dialer Angkasa Raya Teluk Kuantan pada saat ini. Tujuan dari 
analisa terhadap sistem yang lama yaitu untuk mendapatkan solusi yang lebih baik dengan melihat kelemahan-kelemahan dari sistem tersebut.

Berdasarkan kelemahan yang ada pada sistem yang pada umumnya diterapkan pada dealer dan bengkel sepeda motor perlu dilakukan pengembangan terhadap sistem yang ada. Diharapkan dengan sistem yang diusukan ini dapat mengahasilkan laporan (output) atau informasi yang lebih berkualitas. Adapun sistem yang diusulkan adalah sebagai berikut:

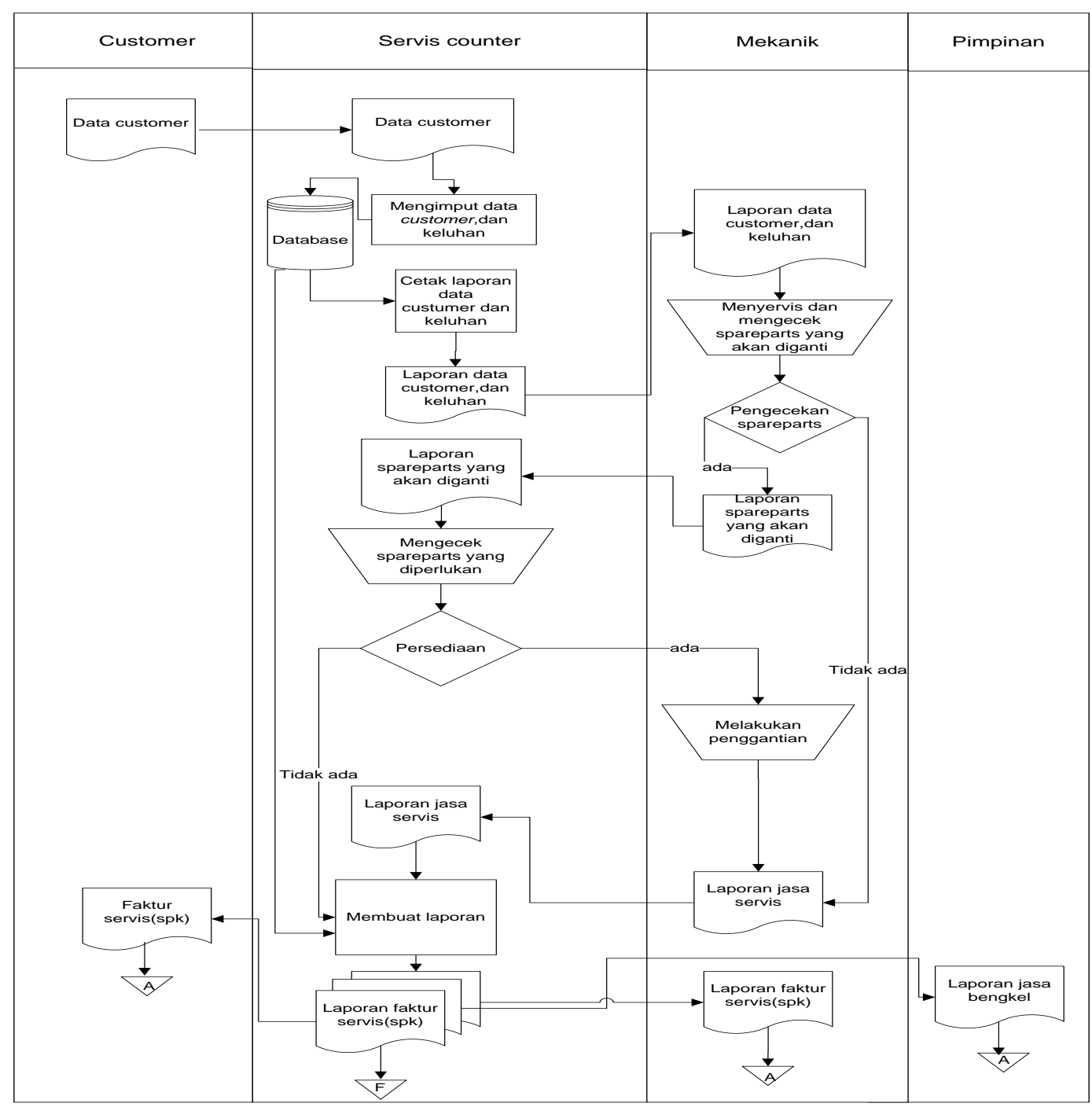

Gambar 1. Pra-Analisa Sistem 


\section{Desain Global}

Desain Global merupakan suatu sistem yang menggambarkan sistem secara keseluruhan. Tujuan sistem global ini adalah untuk menerangkan hubungan dari sub sistem yang nantinya sistem tersebut menjadi satu kesatuan yang terintegrasi.

Perlunya perancangan sistem yang ada adalah untuk memecahkan masalah yang bersifat umum yang dapat dilakukan dengan berbagai aplikasi. Dalam merancang suatu program yang sangat diutamakan adalah output, bagaimana output tersebut bisa dimengerti oleh pemakai (user), Setelah itu dapat pula ditemukan input, file dan proses dari program yang akan dirancang nantinya.

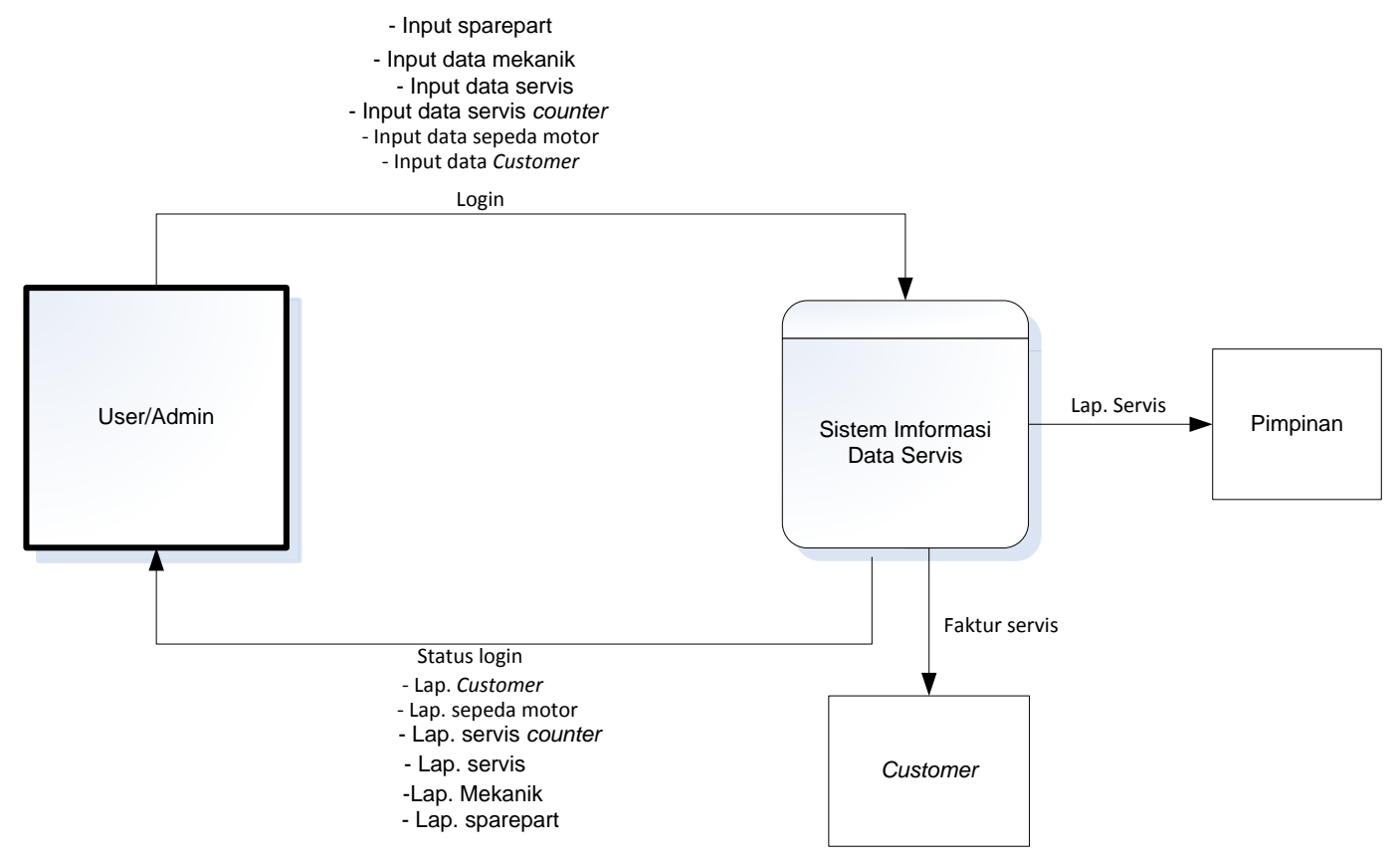

Gambar 2. Context Diagram 


\section{Data Flow Diagram (DFD)}

Data Flow Diagram (DFD) ini merupakan diagram yang menggunakan notasi-notasi yang menggambarkan arus dari sistem dalam Data Flow Diagram (DFD) sering digunakan untuk menggambarkan suatu sistem secara logika tanpa mempertimbangkan lingkungan fisik dimana data tersebut disimpan.

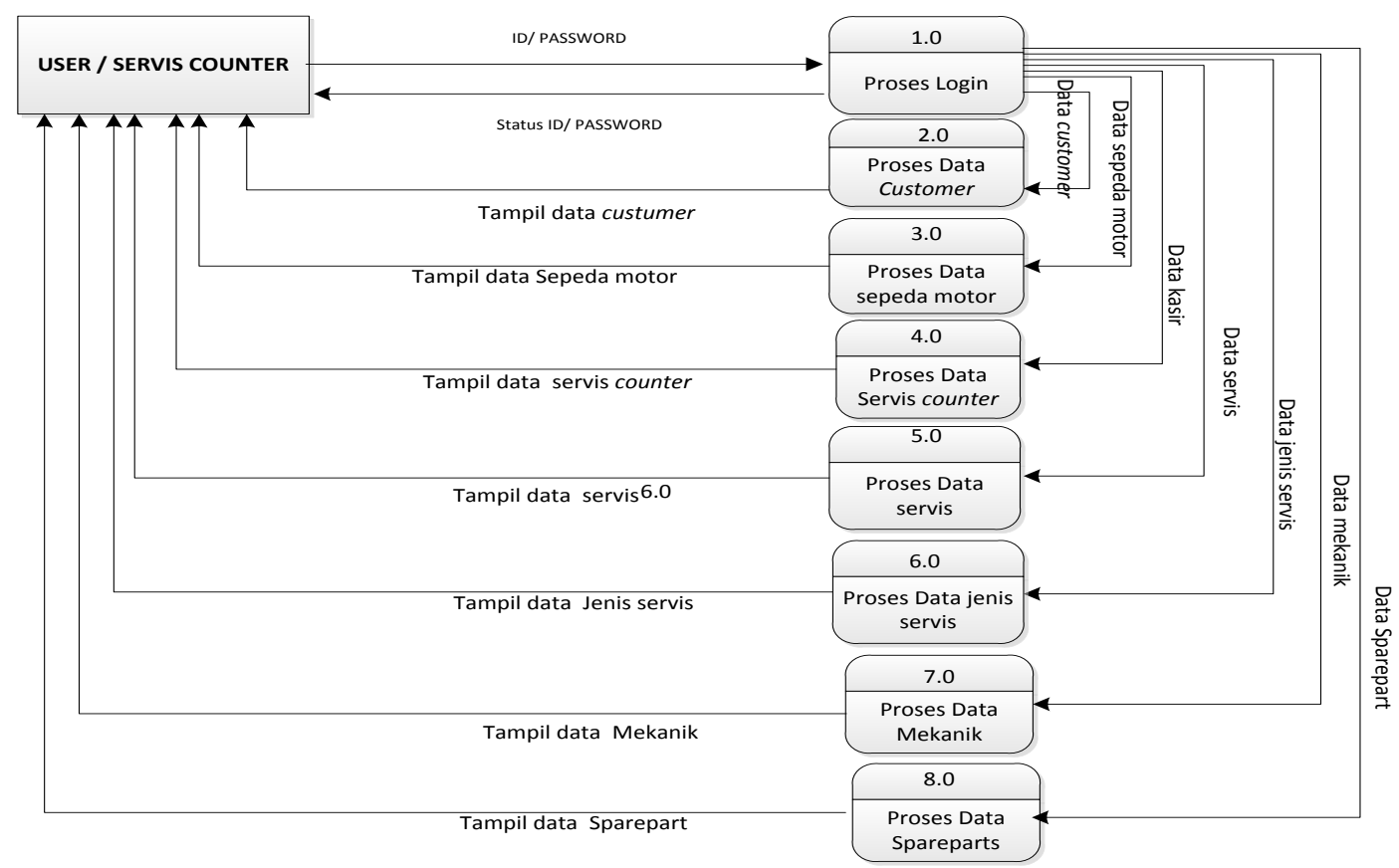

Gambar 3. Diagram Alir Data level 0

\section{Entity Relationship Diagram (ERD)}

Pada Entity Relationship Diagram (ERD) akan menjelaskan bagaimana hubungan antara, custumer, servis counter, sepeda motor,jasa/ servis, mekanik, dan user. Berikut gambar Entity Relationship Diaghram. 


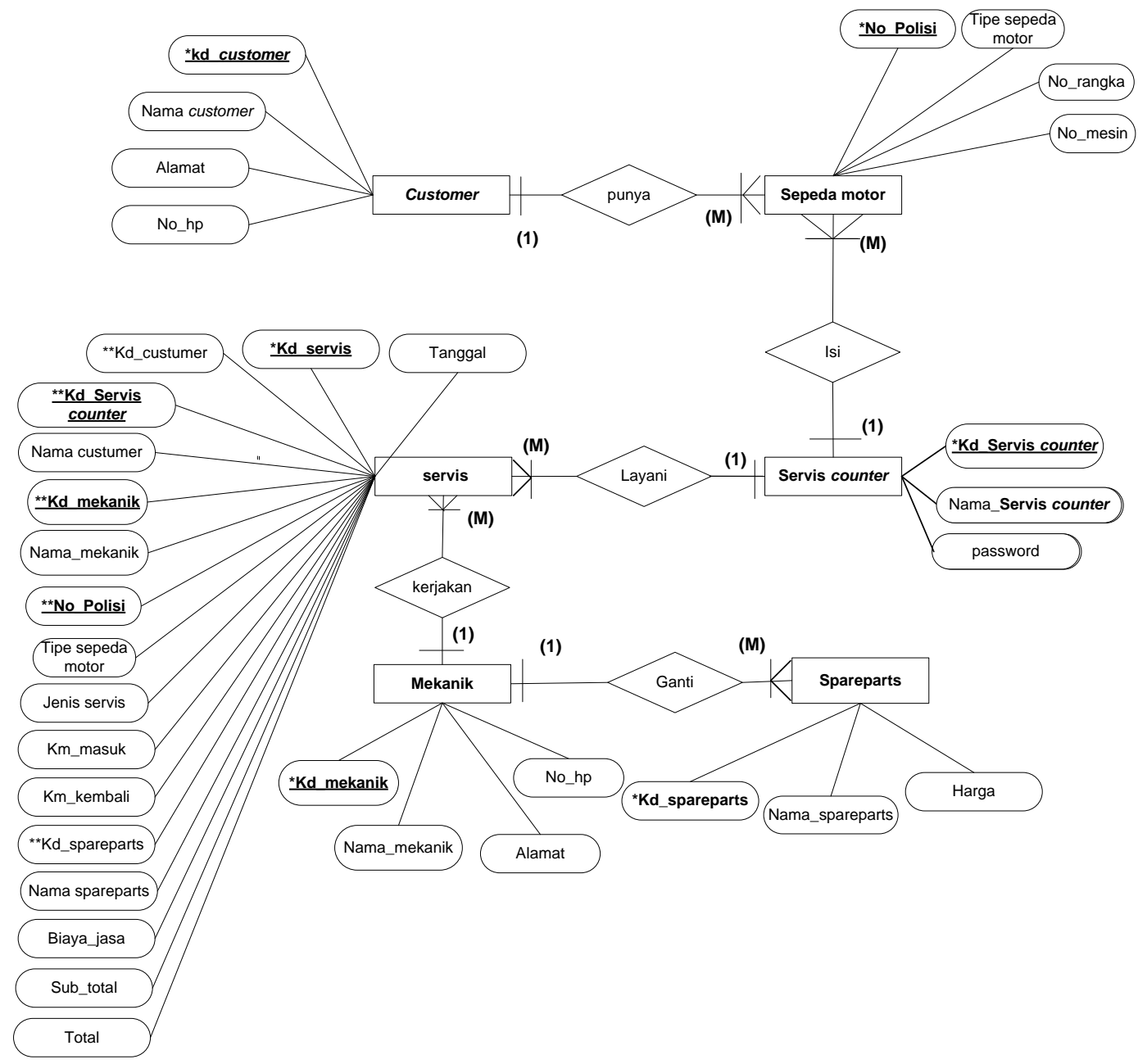

Gambar 4. Entity Relationship Diaghram (ERD)

\section{Desain Struktur Tabel}

Suatu perancangan sistem tidak bisa lepas dari perancangan keluaran dan masukan. Perancangan masukan yang terencana dan terkoordinasi akan memudahkan pembuatan rancangan program ini, disebabkan karena data masukan sangat berpengaruh. Struktur tabel berfungsi untuk memperlihatkan jenjang dari program yang akan dikembangkan. 


\section{RANCANGAN APLIKASI}

\section{Struktur Menu}

Merupakan tampilan pada layar yang menunjukkan bagian-bagian dari program yang akan dikerjakan. Pada menu utama terdapat beberapa pilihan/ proses yang mempunyai kegiatan sendiri yang harus dikerjakan. Adapun struktur program dari perancangan menu utama dapat dilihat pada gambar di bawah ini :

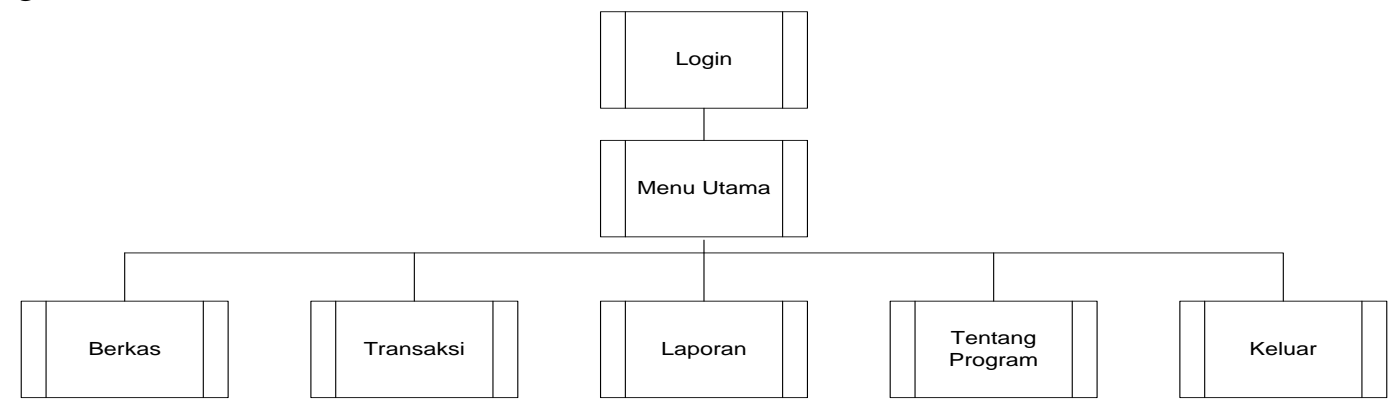

Gambar 5. Struktur Menu

\section{Desain Output}

Keluaran atau (output) atau yang lebih dikenal dengan informasi merupakan salah satu tujuan dari kegiatan pembuatan sistem, informasi yang baik akan mudah dalam penggunaannya sebagai dasar dalam pengambilan keputusan. Informasi yang akan dihasilkan pada Perancangan Sistem Informasi Pengolahan Data Servis Sepeda Motor. 
Rancangan Laporan Data Customer

\section{BENGKEL YAMAHA ANGKASA RAYA TELUK KUANTAN}

Jl. Iman munanandar, depan pasar lumpur Teluk Kuantan

\begin{tabular}{|c|c|c|c|}
\hline $\begin{array}{c}\text { Kd Customer/ } \\
\text { Nomor polisi }\end{array}$ & $\begin{array}{c}\text { Nama/ type sepeda } \\
\text { motor }\end{array}$ & $\begin{array}{c}\text { Alamat/ no } \\
\text { rangka }\end{array}$ & $\begin{array}{c}\text { No telepon/ } \\
\text { no mesin }\end{array}$ \\
\hline & & & \\
& & & \\
\hline
\end{tabular}

Teluk Kuantan, 99/99/9999

Pimpinan

(Gunawan

Tanuji)

Gambar 6. Rancangan Laporan Data Customer 
Rancangan Laporan Data Servis/ Hari

\section{BENGKEL YAMAHA ANGKASA RAYA TELUK KUANTAN}

Jl. Iman munanandar, depan pasar lumpur Teluk Kuantan Data servis tanggal $\mathrm{xx} / \mathbf{x x} / \mathbf{x x x x}$

Kd_servis

Nm_Servis counter : $\mathbf{x x x x x}$

Km masuk

Jenis servis
$: \mathbf{x x x x x}$

$: \mathbf{x x x x x}$

$: \mathbf{x x x x x}$
Nama Costumer : $\mathbf{x x x x x}$

Nm_mekanik : $\mathbf{x x x x x}$

Km kembali $\quad: \mathbf{x x x x x}$

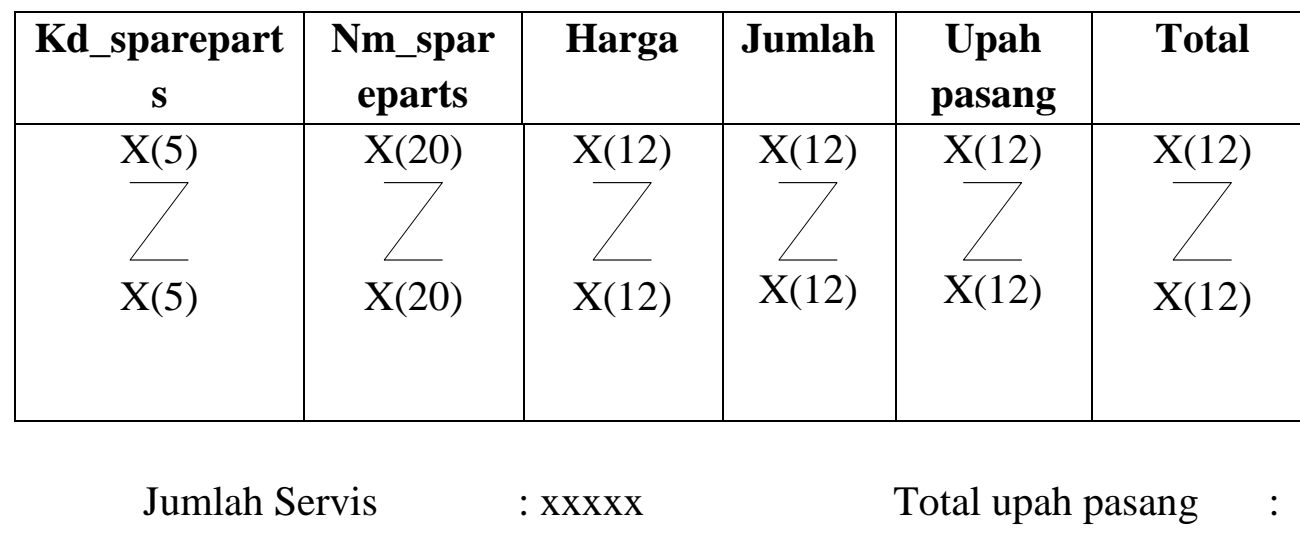

$\operatorname{xxxxxx}$

Jumlah pendapatan $\quad: \operatorname{xxxx}$

Total :

$\operatorname{xxxxxx}$

Teluk Kuantan, 99/99/9999

Pimpinan

(Direktur) 
Gambar 7. Rancangan Laporan Data Servis/ Hari

\section{Form Menu Utama}

Form Menu Utama adalah form yang akan pertama kali tampil pada Perancangan Sistem Informasi Pengolahan Data Servis Sepeda Motor Yamaha Angkasa Raya Teluk Kuantan setelah pengguna melakukan login yaitu Berkas, Transaksi, Laporan, Tentang program, dan Keluar. Untuk lebih jelasnya lihat gambar berikut.

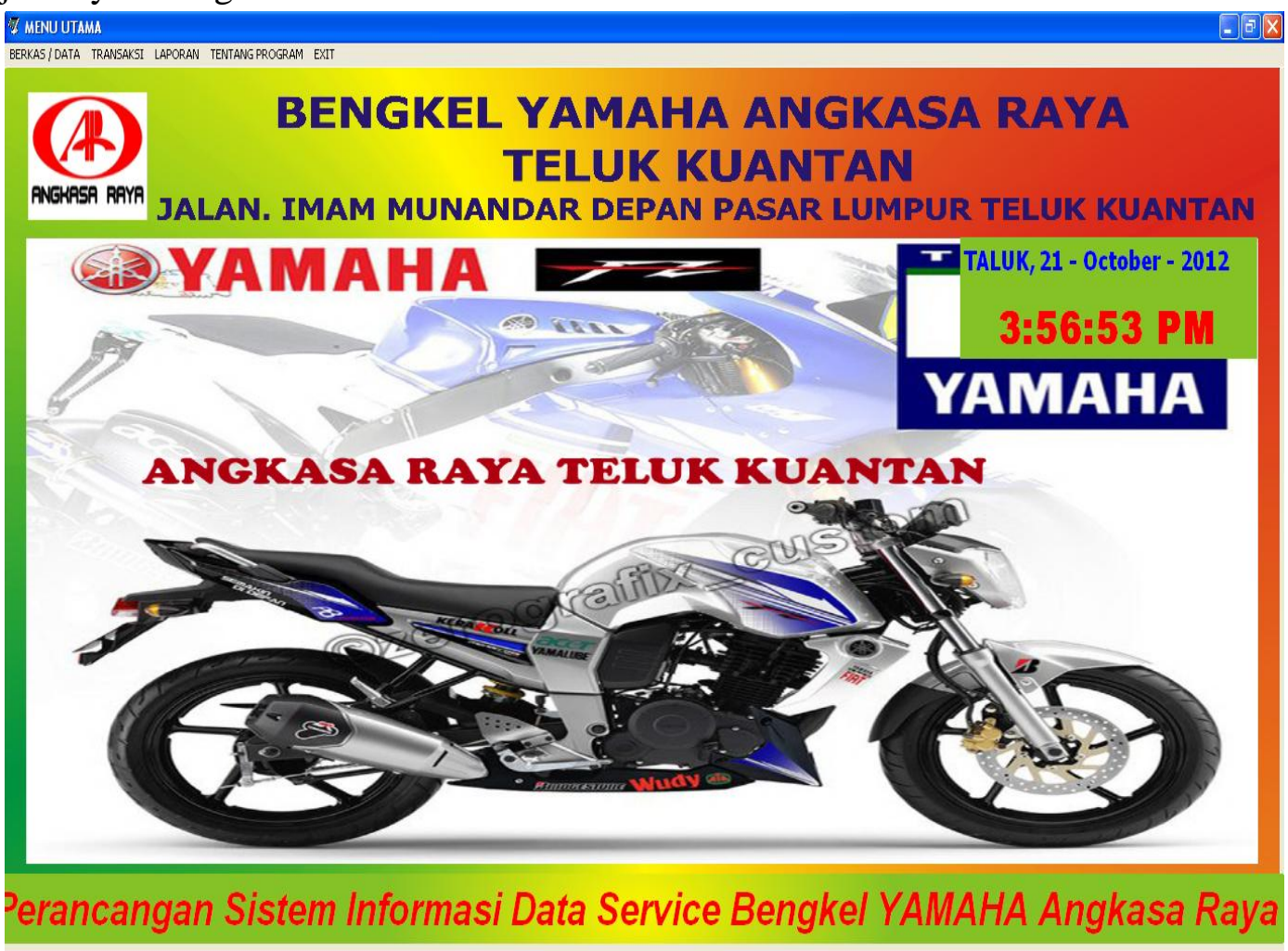

Gambar 8. Form Menu Utama

\section{Form Input Data}

Form ini berguna untuk mengentrikan atau memasukan data custumer yang terdiri dari Kode customer, Nama customer, Alamat, dan No_Handphone, setelah selesai mengentrikan data tekan tombol save(simpan) untuk menyimpan data, tekan tombol edit jika ingin mengubah data tersebut, tekan tombol delete jika ingin menghapus data, dan terakhir tekan tombol keluar jika telah selesai mengentrikan data, dan kembali ke menu utama. Untuk lebih jelasnya lihat gambar berikut. 


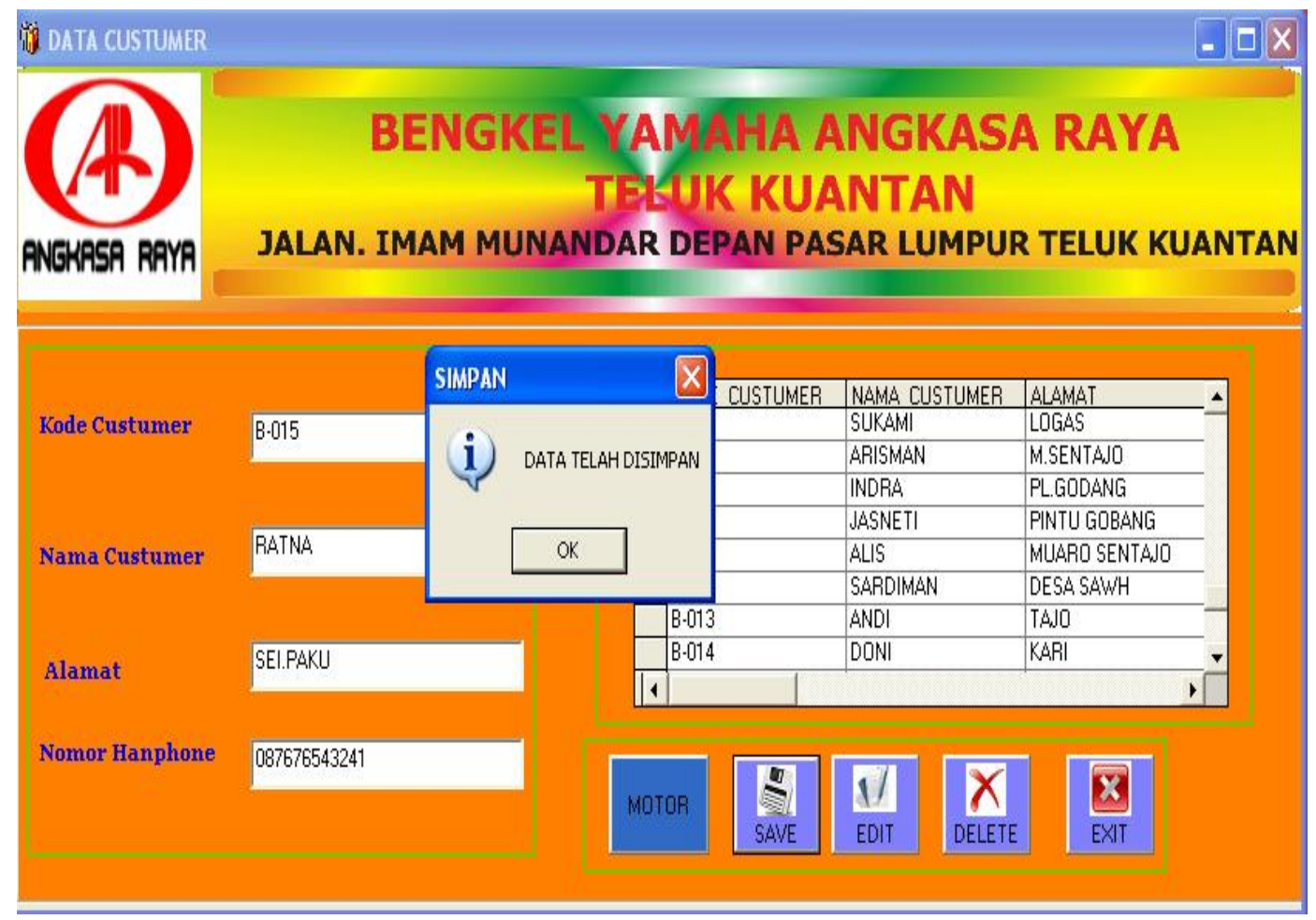

Gambar 9. Form Customer

\section{Form Proses data Servis}

Form ini berguna untuk mengentrikan atau memasukan data servis yang terdiri dari Kd_Custumer, Nama customer, Kd_Mekanik, Nama mekanik, Nomor_polisi, tipe sepeda motor, jenis sepeda motor, kilometer masuk, kilo meter kembali, kemudian secara otomatis Kode_servis counter dan nama servis counter akan muncul, Kode_barang/jasa, nama_barang, harga, upah pasang, total, jumlah total. setelah selesai mengentrikan data, tekan tombol edit jika ingin mengubah data tersebut, tekan tekan tombol batal jika ingin membatalkan data, tekan tombol bayar maka akan muncul tabel pembayaran, yang terdiri dari total, total bayar, diskon, bayar dan kembalian. dan tekan tombol ok. Dan tekan tombol save untuk menyimpan data tekan tombol keluar jika telah selesai mengentrikan data, dan kembali ke menu utama. Untuk lebih jelasnya lihat gambar berikut. 


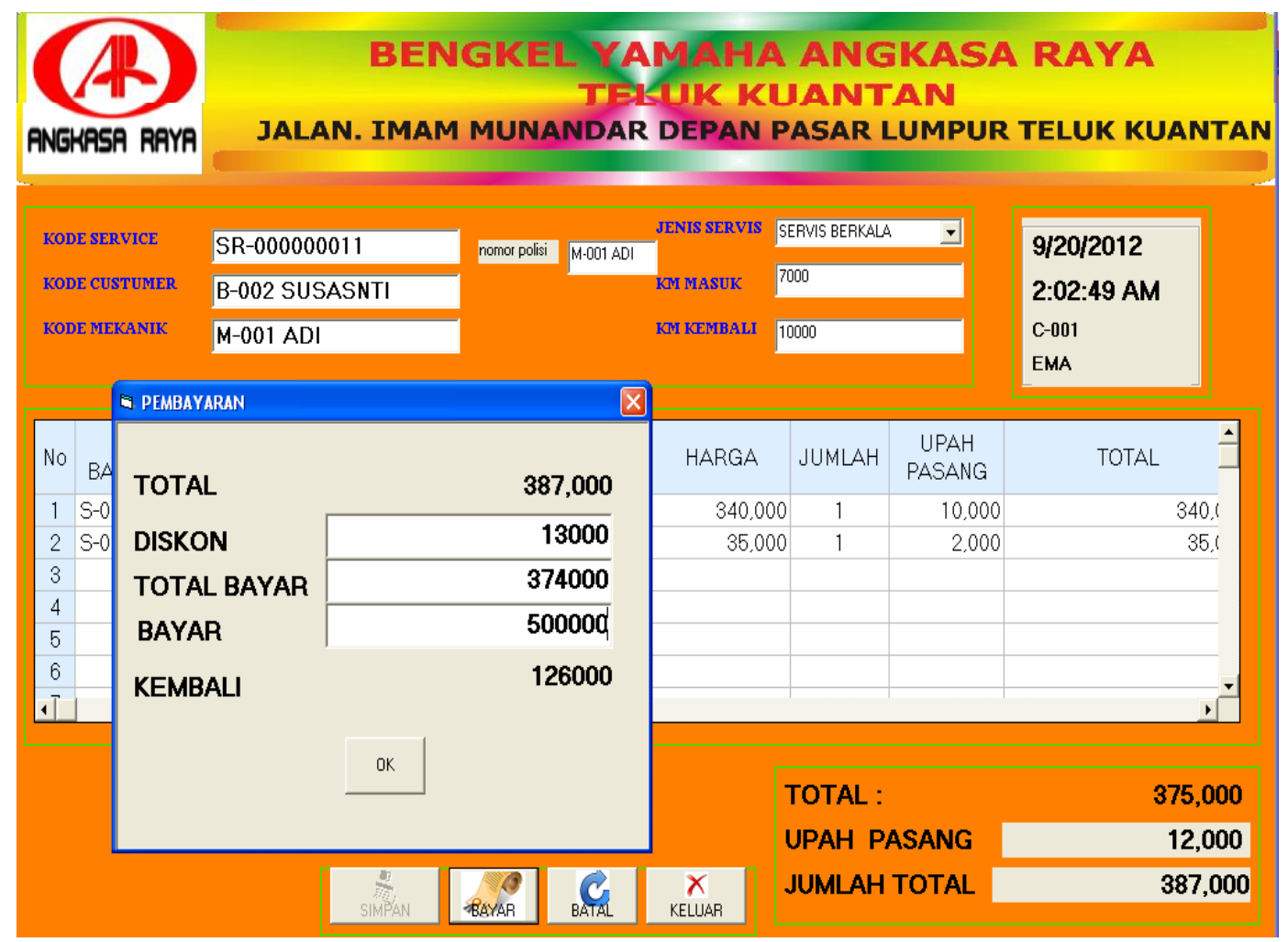

Gambar 10. Form Data servis

\section{Laporan Data Servis Perbulan}

Menu ini berguna untuk menampilkan data servis perbulan secara keseluruhan, mulai dari KSd_servis, nama servis counter, nama mekanik, jenis servis, nama customer, kilometer masuk dan kilometer kembali. Cara menjalankannya cukup mudah yaitu tinggal mengklik menu laporan dan pilih laporan, kemudian akan muncul gambar seperti berikut ini. 


\begin{tabular}{|c|c|c|c|c|c|}
\hline RNGKRSA RAYA & \multicolumn{5}{|c|}{$\begin{array}{l}\text { BENGKEL AAN } \\
\text { TFHUK KUANTAN } \\
\text { JALAN. IMAM MUNANDAR DEPAN PASAR LUMPUR TELUV }\end{array}$} \\
\hline \multicolumn{6}{|c|}{$\begin{array}{ll}\text { DATA SERVIS BULAN } 92012 \quad \text { LAPORAN DATA SERVIS }\end{array}$} \\
\hline KODE SERVIS & \multicolumn{5}{|l|}{ SR-000000001 } \\
\hline NAMA COUNTER & EMA & \multicolumn{2}{|c|}{ NAMA COSTUMER } & \multicolumn{2}{|l|}{ ALI } \\
\hline NAMA MEKANNK & $\mathrm{ADI}$ & \multicolumn{2}{|c|}{ KM MASUK } & \multicolumn{2}{|l|}{1000} \\
\hline JENIS SERVIS & SERVIS GRATIS & \multicolumn{2}{|c|}{ KM KEMBALI } & \multicolumn{2}{|l|}{4000} \\
\hline KODE SPAREPART & NAMA SPAREPART & HARGA & JUMLAH & UPAHPASANG & TOTAL \\
\hline S-003 & $\mathrm{OLI}$ & 23000 & 1 & 2000 & 23000 \\
\hline \multicolumn{5}{|c|}{ TOTAL UPAH PASANG } & 2000 \\
\hline & & \multicolumn{3}{|c|}{ TOTAL } & 23000 \\
\hline KODE SERVIS & \multicolumn{5}{|l|}{ SR-000000003 } \\
\hline NAMA COUNTER & RANTI & \multicolumn{2}{|c|}{ NAMA COSTUMER } & \multicolumn{2}{|l|}{ SUSASNTI } \\
\hline NAMA MEKANIIK & RONI & \multicolumn{2}{|c|}{ KMM MASUK } & \multicolumn{2}{|l|}{12100} \\
\hline JENIS SERVIS & SERVIS BERKALA & \multicolumn{2}{|c|}{ KM KEMBALLI } & \multicolumn{2}{|l|}{15000} \\
\hline
\end{tabular}

\begin{tabular}{|l|l|l|l|r|r|}
\hline KODE SPAREPART & NAMA SPAREPART & HARGA & JUMLAH & UPAH PASANG & \multicolumn{1}{|c|}{ TOTAL } \\
\hline S-003 & OLI & 23000 & 1 & 2000 & 23000 \\
\hline \multicolumn{7}{|c|}{ TOTAL UPAH PASANG } & 2000 \\
\hline \multicolumn{7}{|c|}{ TOTAL } & 23000 \\
\hline
\end{tabular}

Gambar 11. Laporan Data servis / bulan

\section{PENUTUP}

\section{Kesimpulan}

Dari hasil penelitian yang telah dilakukan dan pembahasan dari masing-masing bab, maka dapat diambil kesimpulan bahwa :

1. Berdasarkan penelitian di lapangan bahwa sistem yang masih dilakukan dengan cara manual dan dalam perhitungannya masih mengandalkan alat bantu kalkulator, kurangnya informasi pemantauan suku cadang secara aktual dan real time, belum efektifnya pengecekan ketersediaan Spareparts.

2. Dengan adanya sistem yang baru, sistem mampu menjawab semua permasalahan yang ada, mulai dari pencatatan data customer, transaksi, sampai dengan pembuatan laporan. 


\section{Saran}

Berdasarkan penelitian yang telah dilakukan, maka penulis memberikan beberapa saran yang dapat disesuaikan dengan kebutuhan sistem ini, yaitu :

1. Perlunya penerapan sistem yang baru supaya bisa memberikan pelayanan yang baik (Good Service.

2. Dalam sistem informasi yang dibangun hanya membahas pembayaran tunai saja, alangkah baiknya jika dilengkapi dengan adanya pembayaran secara kredit.

3. Dalam menjalankan tugasnya karyawan harus diberikan pelatihan atau panduan untuk mengoperasikan sistem yang baru ini.

\section{DAFTAR PUSTAKA}

Abdul Kadir, Pengenalan Sistem Informasi(Andi Offset, 2002),

Komunitas eLearning Ilmu Komputer.com (jam 20.00 ,12 mei 2012)

Arief Ramadhan, Visual Basic 6.0 (Elex Media Komputindo, 2004).

http://www.visualbasicindonesia.com (jam 20.10, 20 mei 2012, )

Dedi Surahman, Perancangan Sistem Pengolahan Data Penjualan Barang Pada Bengkel yamaha Er a giga Pekan Baru ( 2010 )..

http://rofiqtik.files.wordpress.com/2009/01/modul-acces_21.pdf Diakses kamis 28 Maret 2012

Sri Widianti, S. Kom, Pengantar Basis data ( LP3I, 2000 ), hal. 13Tata Sutabri. 